\title{
MAKNA KONOTATIF SYAIR QASIDAH SALAWAT NABI PADA NASKAH MAJELIS DZIKIR DAN SALAWAT PONDOK RUMI UNTUK MAJELIS AL-ASYIQIN JAMBI (KAJIAN SEMANTIK)
}

\author{
Uli Wahyuni $^{1}$, Rini Pujiyanti ${ }^{2}$ \\ Program Studi Pendidikan Bahasa dan Sastra Indonesia, \\ Fakultas Keguruan dan Ilmu Pendidikan, Universitas Batanghari, \\ Jambi \\ Uli09yumna@gmail.com \\ rinipujianti981@gmail.com
}

\begin{abstract}
The aim of this research is to describe the connotative meaning of solawat nabi qasidah. This research uses qualitative approach by using descriptive method. This research is descriptive qualitative. In this research, the data is taken by collecting whole data, choosing the data, and analyzing the data in concluding section. The data is taken from the words of data source. The source of the data is the texts of solawat nabi qasidah. In collecting the data, the texts of solawat nabi qasidah which are related with connotative meaning are read. Based on the analysis, there are 13 connotative meaning on the texts of solawat nabi qasidah. From those 36 titles, there are 8 titles which consist of connotative meaning. There are more than one connotative meaning from each title. Thus, it can be concluded that the texts of solawat nabi qasidah consist of connotative meaning.
\end{abstract}

Keywords: Connotative Meaning, Solawat Nabi Qasidah

\footnotetext{
${ }^{1}$ Dosen Program Studi Pendidikan Bahasa dan Sastra Indonesia, Fakultas Keguruan dan Ilmu Pendidikan, Universitas Batanghari, Jambi

${ }^{2}$ Mahasiswa Program Studi Pendidikan Bahasa dan Sastra Indonesia, Fakultas Keguruan dan Ilmu Pendidikan, Universitas Batanghari, Jamb 


\section{PENDAHULUAN}

Bahasa tidak terlepas dari berbagai kemungkinan perubahan yang dapat terjadi pada tataran fonologi, morfologi, sintaksis dan semantik. Pada setiap waktu mungkin saja ada kosakata baru yang muncul, tetapi juga ada kosakata lama yang tenggelam atau tidak digunakan lagi. Meskipun bahasa mempunyai kaidah atau pola tertentu yang sama, namun bahasa itu juga digunakan oleh seseorang yang mempunyai latar belakang sosial dan kebiasaan berbeda, sehingga bahasa itu menjadi beragam yang dapat digunakan oleh manusia. Hal ini juga menimbulkan perbedaan struktur bahasa dan makna yang beragam. Menurut Rahima (2017:255) Setiap teks mempunyai komponen struktur bahasa dan semantik yang berbeda-beda.

Bahasa digunakan oleh manusia untuk melakukan interaksi atau berkomunikasi dengan sesama dalam kehidupan bermasyarakat. Bahasa dan manusia merupakan dua hal yang tidak dapat dipisahkan, dalam arti keduanya saling berhubungan. Bahasa merupakan alat komunikasi yang paling penting bagi manusia karena dengan bahasa manusia dapat mengekspresikan apa yang ada dalam pikirannya. Agar komunikasi dapat berlangsung dengan baik, manusia harus menguasai keterampilan berbahasa karena hal tersebut mencerminkan pikiran, semakin terampil seseorang berbahasa maka semakin cerah dan jelas pikirannya. Bahasa juga termasuk dalam karya sastra.

Karya sastra merupakan suatu bentuk karangan yang berisi tentang keindahan. Seorang sastrawan menulis sebuah karya sastra dengan menuliskan suatu ide yang ada di dalam pikirannya, sehingga menciptakan karya sastra yang bisa membuat seseorang merasakan perasaan senang, bahagia, haru, damai, bahkan benci. Selain itu, nilai-nilai yang terkandung dalam karya sastra sangat baik untuk pedoman dalam kehidupan yang disampaikan penulis kepada pembaca. Pada dasarnya karya sastra banyak memiliki berbagai macam karakteristik yang berbeda-beda. Hal inilah yang membuat keindahan dalam karya sastra, maka dari itu setiap sastrawan juga menciptakan sesuai dengan apa yang telah menjadi keahliannya. Secara garis besar karya sastra dikelompokkan menjadi tiga bagian yaitu prosa, drama dan puisi.

Puisi adalah salah satu bentuk bagian dari karya sastra. Puisi merupakan bagian dari bentuk dan hasil pekerjaan seni yang kreaktif yang dibuat oleh manusia. Puisi juga termasuk ungkapan perasaan dari penyair yang mempunyai irama, ritma, dan rima dengan bahasa imajinatif dan disusun secara padat serta penuh makna. Puisi akan lebih kuat dan mengena kepada hati pembaca jika dibuat dari hati, kemudian dituangkan dengan cara imajinatif, dan berkonsentrasi dalam penyusunan bahasa pada struktur fiksi dan batinnya, puisi juga termasuk dalam bentuk syair.

Syair merupakan puisi atau karangan dalam sastra melayu lama, dengan bentuk terikat yang mementingkan irama dan sajak. Syair memiliki bentuk susunan atau rangkaian kata yang bernada. Syair berupa ekspresi seseorang tentang suatu hal yang sudah dilihat, didengar, maupun di alaminya. Dalam mengekspresikan pengalamannya, penyair atau penulis melakukan permainan kata-kata dan bahasa untuk menciptakan daya tarik dan ciri khas terhadap syairnya. Syair bukanlah kumpulan kata yang asal dan tidak memiliki makna, justru ia hadir membawa makna isi yang berhubung dengan kias ibarat, sindirian, nasihat, pengajaran, agama, dan juga berisikan 
sejarah atau dongeng. Jadi, puisi dan syair termasuk dalam karya sastra yang keduanya sama-sama hasil dari pemikiran seseorang. Melalui bahasa yang memiliki makna. Ilmu bahasa yang memiliki makna disebut dengan semantik, dengan menggunakan media bahasa yang mengandung makna, dalam ilmu bahasa, hal ini disebut dengan istilah semantik.

Semantik adalah lambanglambang atau tanda-tanda yang menyatakan makna, hubungan makna yang satu dengan yang lain, semantik pencangkup makna-makna kata, perkembangannya dan perubahannya. Disisi lain, Kata semantik ini dapat digunakan dalam bidang linguistik yang mempelajari hubungan dengan tandatanda linguistik dengan hal-hal yang yang ditandainya. Atau dengan kata lain semantik itu adalah bidang studi dalam linguistik yang mempelajari makna atau arti dalam bahasa. Oleh karena itu, kata semantik dapat diartikan sebagai ilmu tentang makna atau tentang arti yaitu salah satu dari tiga tataran analisis bahasa: fonologi, gramatikal, dan semantik. Chaer, (1990:2).

Menurut uraian di atas, maka peneliti tertarik untuk mengkaji makna dalam syair qasidah salawat nabi. Makna yang akan peneliti kaji adalah makna konotatif dalam qasidah salawat nabi pada naskah majelis dzikir dan salawat pondok rumi untuk majelis al-asyiqin Jambi ini, terdiri dari 36 judul qasidah dan 74 halaman yang berisi salawat yang berupa syair bernuansa islam atau keagamaan. Penulisan naskah ini membutuhkan waktu yang sangat lama karena di dalam naskah ditulis dengan bahasa Arab dan tulisan indonesia beserta terjemahannya. Naskah ini bernuansa islami yang dapat memberikan kesejukan hati dan ketenangan bagi pembacanya, pembaca juga lebih banyak memahami tentang qasidah salawat nabi. Makna tidak terlepas dari bidang semantik, karena dalam semantik mempelajari dan menelaah makna.

Makna adalah suatu arti atau maksud yang disebut dengan suatu kata, tidak hanya kata, makna juga bisa menimbulkan reaksi kepada pendengar atau pembaca. Makna juga termasuk dalam ujaran yang berhubungan dengan bunyi atau acuannya.

Makna juga mempunyai arti atau maksud yang terkandung di dalam sebuah aturan atau ungkapan yang disampaikan melalui lisan atau tulisan. Disisi lain, makna adalah apa yang kita artikan atau apa yang akan kita maksudkan merupakan pengaruh suatu bahasa dalam pemikirannya, yang berhubungan dengan alam luar atau ujaran yang sesuai dengan mkna yang ditunjukkan.

Alasan peneliti untuk meneliti naskah ini, agar pembaca mengetahui makna konotatif yang terdapat di dalam qasidah salawat nabi pada naskah majelis dzikir dan salawat pondok rumi untuk majelis al-asyiqin Jambi. Syair qasidah salawat nabi ini biasanya dimainkan beriringan dengan Hadrah, yaitu sejenis alat musik yang sering digunakan untuk mengiringi lantunan qasidah salawat nabi. Syair salawat nabi ini disebut dengan nyayian yang bernuansa keislaman atau keagamaan. Peneliti meneliti makna konotatif ini adalah pada naskah peneliti terdapat beberapa makna konotatif. Makna konotatif yaitu makna tambahan disebut dengan makna kias, makna kias yaitu makna yan sama dengan makna konotatif.

Dari hasil pengamatan peneliti, bahwa yang terjadi di masyarakat saat ini adalah kurangnya minat untuk membaca atau bersalawat dalam syair qasidah salawat nabi, sehingga masyarakat kurang berpatisipasi dalam mengikuti acara qasidah salawat nabi yang 
bernuansa islam, terutama di kalangan remaja. Remaja saat ini tidak mengetahui apa itu qasidah salawat nabi, remaja lebih suka membaca novel dan buku cerita lainnya dari pada membaca syair qasidah salawat nabi, padahal guna untuk membaca qasidah salawat nabi atau bersalawat untuk mendekatkan diri kita kepada Allah SWT. Acara-acara ini sering diadakan di masjid-masjid yang diikuti oleh bapak-bapak dan ibu-ibu. Untuk itu, peneliti tertarik melakukan penelitian ini agar kalangan remaja dapat mengikuti acara salawat nabi bersama ibu-ibu dan bapak-bapak yang di adakan di masjid pada acara tertentu. Bukan hanya itu, masyarakat dan kalangan remaja mengetahui makna-makna konotatif yang terdapat dalam teks syair qasidah salawat nabi.

Peneliti memilih syair adalah sesuai dengan judul peneliti di atas, peneliti menganalisis makna pada syair qasidah salawat nabi, karena objek peneliti adalah naskah qasidah yang isi di dalamnya terdapat syair qasidah salawat nabi. Peneliti meneliti qasidah adalah karna peneliti tertarik untuk meneliti bagian dari syair tulisan atau yang berisi tentang nuansa keislaman, karna menurut peneliti tidak banyak orang meneliti tentang syair qasidah salawat nabi. Peneliti menetapkan judul penelitian yakni, "Analisis Makna Konotatif Syair Qasidah Salawat Nabi pada Naskah Majelis Dzikir dan Salawat Pondok Rumi untuk Majelis Al-Asyiqin Jambi (Kajian Semantik).

Berdasarkan latar belakang, dalam penelitian ini memerlukan fokus permasalahan dan pertanyaan penelitian. Berikut penjelasan fokus permasalahan dan pertanyaan penelitian. Fokus permasalahannya adalah mengingat keterbatasan peneliti baik dari segi waktu serta kemampuan peneulis sendiri, untuk itu perlu dibuat fokus permasalahan penelitian. Adapun fokus permasalahan penelitian ini adalah hanya mengkaji makna konotatif di dalam naskah syair qasidah salawat nabi, yaitu "Analisis Makna Konotatif pada syair qasidah salawat nabi naskah majelis dzikir dan salawat pondok rumi untuk majelis alasyiqin Jambi (kajian semantik)". Pertanyaan penelitian adalah agar permasalahan dalam penelitian ini menjadi jelas dan terarah, maka perlu adanya pertanyaan penelitian. Berdasarkan latar belakang di atas maka dapat ditarik sebuah kesimpulan berbentuk pertanyaan penelitian yaitu. Bagaimanakah makna konotatif syair qasidah salawat nabi pada naskah majelis dzikir dan salawat pondok rumi untuk majelis al-asyiqin Jambi ?

Tujuan penelitian merupakan sesuatu yang ingin dicapai dari kegiatan yang telah dilakukan mengenai permasalahan yang ada. Berdasarkan pertanyaan penelitian yang telah di paparkan, maka tujuan penelitian ini yaitu untuk mendeskripsikan makna konotatif pada syair qasidah salawat nabi pada naskah majelis dzikir dan salawat pondok rumi untuk majelis al-asiqin Jambi. Adapun manfaat penelitian ini secara teoretis Penelitian ini memberikan kontribusi terhadap suatu penelitian, penelitian ini secara teoretis akan memberikan dasar-dasar teori tentang makna konotatif pada sebuah syair qasidah salawat nabi. Adapun manfaat teoretis yang diharapkan dari peneliti ini adalah sebagai berikut:

1. Penelitian ini dapat memperkaya teori-teori semantik, khususnya yang terkait dengan makna.

2. Penelitian ini dapat dijadikan sebagai referensi tentang teori semantik untuk peneliti berikutnya yang meneliti tentang makna dalam kajian semantik. 
3. Penelitian ini diharapkan dapat bermanfaat bagi pengembangan ilmu pengetahuan dan untuk penelitian berikutnya.

Selain memberikan manfaat teoritis, penelitian ini juga memberikan manfaat praktis antara lain:

1. Bagi peneliti

Hasil penelitian ini dapat dapat menjadi jawaban dari masalah yang dirumuskan. Selain itu, dengan selesainya penelitian ini diharapkan dapat menjadi motivasi bagi peneliti untuk semakin aktif menyumbangkan hasil karya ilmiah bagi dunia sastra dan pendidikan.

2. Bagi pembaca

Hasil penelitian ini bagi pembaca diharapkan dapat lebih memahami tentang makna konotatif yang terdapat di dalam naskah syair qasidah salawat nabi. Selain itu, diharapkan kepada para pembaca agar mampu lebih jelih memilih syair-syair qasidah salawat nabi bernuansa islam yang memiliki manfaat dan yang memberikan pesan-pesan dakwah yang bermanfaat bagi pembaca.

3. Bagi pendidikan

Hasil penelitian ini bagi pendidikandiharapkan bermanfaat bagi pendidik karena dalam pembelajaran pendidik dapat mengetahui dan memahami pentingnya mengetahui kesenian syair qasidah pada daerahnya, dan bukan hanya mengetahui kesenisannya, tetapi harus dilihat juga makna konotatif yang terkandung di dalam naskah qasidah salawat nabi, dan dapat dijadikan contoh untuk generasi penerus.

\section{Bagi masyarakat}

Hasil penelitian ini bagi masyarakat diharapkan dapat di jadikan sebagai panduan untuk meningkatkan keterampilan memainkan dan bersyair dalam qasidah, agar menjadikan masyarakat tersebut aktif dalam berkarya dan mengetahui makna yang terkandung di dalam qasidah salawat nabi.

Adapun kajian penelitian ini, menurut Blach dan Tragrer, Joseph Bram (dalam Hidayat 2006:22) "Bahasa indonesia adalah suatu sistem yang berstruktur dari simbol-simbol bunyi arbitrer yang dipergunakan oleh para anggota suatu kelompok sosial sebagai alat bergaul satu sama lain”. Sedangkan Menurut Abdul Chaer (2011:1) "Bahasa adalah suatu sistem lambang berupa bunyi, bersifat arbitrer, digunakan oleh suatu masyarakat tutur untuk bekerja sama, berkomunikasi, dan mengidentifikasi diri”.

\section{Dalam Kamus Besar Bahasa} Indonesia memberikan pengertian "bahasa" ke dalam tiga batasan, yaitu: (1) sistem lambang bunyi berartikulasi (yang di hasilkan alat-alat ucap) yang bersifat sewanang-wenang (arbitrer, pen) dan konvensional yang dipakai sebagai alat komunikasi untuk melahirkan perasaan dan pikiran; 2) perkataan-perkataan yang dipakai oleh suatu bangsa (suku bangsa, daerah, negara, dsb); 3) percakapan (perkataan) yang baik: sopan santun, tingkah laku yang baik. Menurut Hidayat (2006:22). "Bahasa merupakan alat komunikasi yang mengandung beberapa sifat yakni, sistematik, mana suka, ujar, manusiawi, dan komunikatif'. Menurut Santosa, dkk (2008:1-2), "Bahasa ialah alat komunikasi antara anggota masyarakat berupa simbol bunyi yang dihasilkan oleh alat ucap manusia". Menurut Keraf (1997:1) melalui bunyi yang dikeluarkan oleh alat ucap manusia, manusia dapat saling berkomunikasi untuk menyampaikan pesan yang di maksud kepada orang lain. Bahasa`merupakan sebagai alat penghubung aktifitas dalam berkomunikas. "Bahasa adalah alat yang ampuh untuk menghubungkan dunia seseorang dengan dunia di luar diri kita, 
dunia seseorang dengan lingkungannya, dunia seseorang dengan alamnya, bahkan dunia seseorang dengan tuhannya”. Menurut Pateda (2011:6).

Dalam berkomunikasi, manusia pada umunya menggunakan bahasa sebagai alat untuk berkomunikasi. "Bahasa terbentuk oleh suatu aturan, kaidah, atau pola-pola tertentu, baik dalam bidang tata bunyi, tata bentuk kata, maupun tata kalimat. Bila aturan, kaidah, atau pola ini dilanggar, maka komunikasi dapat terganggu”. Menurut Chaer (2011:1).

Menurut Sumardjo (dalam Rokhmansyah, 2013:3) "Karya sastra adalah ungkapan pribadi manusia yang berupa pengalaman, pemikiran, perasaan, ide, semangat keyakinan dalam suatu bentuk gambaran konkret yang membangkitkan pesona dengan alat bahasa".

"Karya sastra adalah tulisan atau karangan yang mengandung nilai-nilai kebaikan yang ditulis dengan bahasa yang indah". Kosasih (2012:1). Menurut Rene Wellek dan Austin Warren (1993:1) "Sastra adalah suatu kegiatan kreaktif, sebuah karya seni. Sastra juga dianggap sebagai karya imajinatif, fiktif, dan inovatif. Secara etimologis, sastra sendiri diartikan sebagai alat untuk mengajar, buku petunjuk, ataupun buku petunjuk pengajaran”. Dari penjelasan di atas, peneliti dapat menyimpulkan bahwa karya sastra merupakan sebuah karya yang kreaktif yang otonom, yang lahir dari ungkapan seorang sastrawan untuk menuangkan ide-ide, pemikiran, perasaan, pandangan, dan semua kegiatan mental manusia dalam karya sastra.

Dalam melakukan penelitian penulis perlu mrlakukan penelitian yang relevan guna untuk mempermudah penulis dalam meneliti. Penelitian mengenai tentang syair qasidah salawat nabi yang pernah diteliti oleh peneliti lain. Ada beberapa peneliti yang dapat dijadikan sebagai referensi diantaranya:

1. Peneitian yang dilakukan oleh Aris

Sujarno Mahasiswa Universitas

Muhammadiyah Purwokerto dalam

skripsi (2010) dengan judul “Analisis

Semantik dalam Syair Kesenian

Cowong di Desa Pekuncen

Kecematan Kroya Kabupaten

Cilacap".

2. Penelitian yang dilakukan oleh Evi

Yuniarti dalam skripsi (2014)

dengan judul "Kajian Semantik Nama

Panggilanan Unik Siswa di Sekolah

Madrasah Aliyah Negeri Kraya

Tahun Pelajaran 2013-2014”.

3. Penelitian yang dilakukan oleh

Sunyiartiningsih Mahasiswa

Universitas Muhammadiyah

Puwokarto, Program Studi

Pendidikan Bahasa dan Sastra

Indonesia, dalam skripsi (2013)

dengan judul "Kajian Semantik pada

Syair Lagu Kesenian Tradisional

Kleningan Mekar Rahayu di Desa

Sukarahayu, Kecamatan Langen Sari,

Kota Banjar”.

\section{METODE PENELITIAN}

Jenis penelitian sangatlah penting untuk mencapai tujuan yang diharapkan dalam penelitian. Penelitian belum dapat dilaksanakan sebelum menentukan jenis penelitian yang akan digunakan. Jenis penelitian merupakan cara memahami objek yang menjadi sasaran penelitian. Seorang peneliti dapat memilih satu dari berbagai jenis yang ada sesuai dengan tujuan. "Jenis penelitian berarti cara yang digunakan seseorang peneliti di dalam usaha memecahkan masalah yang diteliti”. Siswantoro (2010:55). Jenis penelitian ini dapat peneliti jadikan sebagai pemahaman suatu objek ataupun 
suatu masalah, dengan adanya jenis penelitian ini mewujudkan terciptanya suatu penelitian dengan baik untuk memahami hasil yang maksimal dalam sebuah penelitian. Jenis penelitian yang digunakan peneliti dalam penelitian ini adalah deskriptif kualitatif. "Deskriptif adalah prosedur pemecahan masalah yang diselidiki dengan menggambarkan atau melukiskan keadaan subjek atau objek penelitian (puisi lama) berdasarkan faktafakta yang tampak atau sebagaimana adanya”. Nawawi (dalam Siswantoro, 2010:56). Dapat peneliti menyimpulkan deskriptif merupakan suatu pemecahan masalah dengan menggambarkan subjek dan objek yang diteliti yang termasuk ke dalam penelitian kualitatif. Penelitian kualitatif merupakan jenis penelitian yang lebih menekankan pada aspek pemahaman secara mendalam terhadap suatu masalah. "Penelitian kualitatif akan melihat segala sesuatu yang terdapat pada objeknya masih bersifat umum, setelah itu akan terdapat tahap orientasi dan deskripsi”. Sugiyono (2013:19).

Data primer merupakan data utama dalah sebuah penelitian. "Data primer adalah data utama, yaitu data yang diseleksi atau diperoleh langsung dari sumbernya tanpa perantara". Siswantoro (2010:70). Sedangkan menurut pendapat Ibrahim (2015:68) "Mengatakan bahwa data primer adalah segala informasi, fakta, dan realitas yang terkait atau relevan dengan penelitian, dimana kaitan atau relevansinya sangat jelas, bahkan secara langsung”. Sumber data adalah subjek dari mana data dapat diteliti”. Arikunto (2010:173).

Teknik pengumpulan data merupakan cara yang dapat digunakan oleh seorang peneliti dalam mengumpulkan data untuk kepentingan penelitian. Teknik pengumpulan data yang digunakan penulis dalam penelitian ini yaitu:

1. Penelitian membaca buku-buku literatur yang ada hubungannya dengan penelitian sebagai sumber informasi atau acuan untuk mengadakan penelitian.

2. Penelitian membaca secara keseluruhan isi dari syair qasidah salawat nabi pada naskah majelis dzikir dan salawat pondok rumi.

3. Peneliti memahami isi syair qasidah salawat nabi pada naskah majelis dzikir dan salawat pondok rumi yang berkaitan dengan makna.

4. Peneliti menandai dan mencatat bagian-bagian dalam syair qasidah Salawat nabi sesuai dengan kepentingan penelitian yaitu makna yang terkandung di dalam syair qasidah salawat nabi pada naskah majelis dzikir dan salawat pondok rumi.

5. Setelah data terkumpul, peneliti kemudian mengklasifikasi data sesuai dengan makna yang terdapat dalam syair qasidah salawat nabi pada naskah majelis dzikir dan salawat pondok rumi.

Menurut Siswantoro (2010:81) "Teknik analisis yang dilakukan dengan pemaparan dalam bentuk deskriptif terhadap masing-masing data secara Fungsional dan Rasional”. Kegiatan analisis data dilakukan dengan langkahlangkah sebagai berikut: Data yang dianalisis dengan melakukan serangkaian teknik analisis data dengan langkah-langkah sebagai berikut:

1. Data yang sudah terkumpul, kemudian dimasukan ke dalam tabel analisis data.

2. Peneliti menganalisis sesuai dengan penggambaran makna yang di analisis dalam syair qasidah salawat nabi pada naskah majelis dzikir dan 
salawat pondok rumi untuk majelis al-asyiqin Jambi.

3. Peneliti mendeskripsikan hasil dari analisis sesuai dengan analisis makna syair qasidah salawat nabi pada naskah majelis dzikir dan salawat pondok rumi untuk majelis al-asyiqin Jambi.

4. Langkah-langkah terakhir dalam penelitian ini peneliti merumuskan dan menarik sesuatu kesimpulan.

\section{HASIL DAN PEMBAHASAN}

Berdasarkan data yang dikumpulkan, maka diperoleh hasil penelitian berupa kata-kata bermakna konotatif yang terdapat pada teks syair qasidah salawat nabi. Sebanyak 13 kalimat dari 36 judul memuat kata-kata bermakna konotatif. Dari 36 judul tersebut hanya terdapat 8 judul yang ditemukan oleh peneliti bermakna konotatif. Dalam satu judul terdapat lebih dari satu kata-kata konotatif. Pembahasan dalam penelitian ini yaitu analisis data hasil penelitian. Data tersebut berupa kutipan dari syair qasidah salawat nabi. Dalam hal ini, terdapat 8 judul dari 36 judul yang diteliti, yang mengandung makna konotatif sebanyak 13 kutipan.

Kutipan-kutipan yang ditemukan tersebut mengandung makna konotatif, sesuai dengan pengertian makna konotatif yang dikemukakan oleh Yayat Sudaryat (2011:25), yaitu makna konotatif adalah makna yang tidak langsung menunjukkan hal, benda, atau objek yang diacunya. Makna konotatif biasanya mengandung perasaan, kenangaan dan tafsiran terhadap objek lain. Makna konotatif merupakan makna yang tidak sebenarnya. Pada judul "Qul Yaa Adzim" terdapat makna konotatif pada kutipan Laksana Singa yang terdapat pada halaman 10 bait ke 16 yang memiliki makna yang tidak sebenarnya. Laksana Singa memiliki makna konotatif yaitu tangguh, kuat, berani sedangkan makna yang sebenarnya berdasarkan KKBI adalah sebagai singa binatang buas dalam bentuknya.

Pada judul "Ya badro tim" terdapat makna konotatif pada kutipan Purnama yang terdapat pada halaman 21 bait ke 1 dan 4 yang memiliki makna yang tidak sebenarnya. Purnama memiliki makna konotatif yaitu penerang dunia, penunjuk jalan bagi umat islam, sedangkan makna yang sebenarnya berdasarkan KKBI adalah bulan purnama pada saat bulan bulan bundar benar.

Pada judul "Assalamu Alayka Zainal Anbiya” terdapat makna konotatif pada kutipan Perhiasan yang terdapat pada halaman 23 bait ke 1,3,11,13 yang memiliki makna yang tidak sebenarnya. Perhiasan memiliki makna konotatif yaitu keindahan pada para nabi sedangkan makna yang sebenarnya berdasarkan KBBI adalah barang yang di pakai untuk berhias. Selanjutnya pada halaman 23 bait ke 9 terdapat kutipan Mahkota Kemuliaan memiliki makna konotatif yaitu derajat kemuliaan yang paling tinggi, sedangkan makna yang sebenarnya berdasarkan KBBI adalah hiasan kepala atau songkok kebesaran bagi raja atau ratu untuk kehormatannya.

Pada judul "Khoirol Bariyah" terdapat makna konotatif pada kutipan Lautan Anugrah yang terdapat pada halaman 34 bait ke 3 yang memiliki makna tidak sebenarnya. Lautan Anugrah memiliki makna konotatif yaitu besarnya nikmat yang telah diberikannya kepada kita, sedangkan makna yang sebenarnya berdasarkan KKBI adalah lautan yang besar pemberian atau karunia untik kita. Selanjtnya Pada halaman 34 bait ke 3 terdapat kutipan Mahkota Keadilan memiliki makna konotatif yaitu suatu keadilan pada yang paling tinggi, 
sedangkan makna yang sebenarnya berdasarkan KBBI adalah mahkota sebagai hiasan kepala dan keadilan perbuatan atau prilaku yang berlaku adil.

Pada judul "Tholama asyku ghoroomi” terdapat makna konotatif pada kutipan Sang Bulan Purnama yang terdapat pada halaman 41 bait ke 8 yang memiliki makna tidak sebenarnya. Sang Bulan Purnama memiliki makna konotatif yaitu nabi muhammad saw sebagai pemeri petunjuk atau kebenaran, sedangkan makna yang sebenarnya berdasarkan KBBI adalah sang melambangkan suatu benda yang dianggap hidup dan bulan benda langit yang mengitari bumi purnama pada saat bulan bundar benar.

Pada judul "Ya Habib, Yaa Habiibi” terdapat makna konotatif pada kutipan Buah Hati yang terdapat pada halaman 54 bait ke 8, 9, 10, 11, 14, 15, 17, 19 memiliki makna yang tidak sebenarnya. Buah Hati memiliki makna konotatif yaitu kesayangan, kecintaan atau yang sangat dicintai, sedangkan makna yang sebenarnya berdasarkan KBBI adalah kekasih, anakku atau yang sangat dicintai. Selanjutnya pada halaman 54 bait ke 12 terdapat kutipan Keharumannya memiliki makna konotatif yaitu kebaikan dan keindahan sifatnya, sedangkan makna yang sebenarnya berdasarkan KBBI adalah kewangiang, sifat-sifat harum atau kebaikan namanya. Selanjutnya pada halaman 54 bait ke 12 terdapat kutipan Mencabut Akal memiliki makna konotatif yaitu mengagumi atau sangat tergila-gila, sedangkan makna yang sebenarnya berdasarkan KBBI adalah mencabut menarik atau keluar, akal daya pikir manusia atau hilangnya akal. Pada judul “Thola' Al Badru Alayna” terdapat makna konotatif pada kutipan Bulan Purnama yang terdapat pada halaman 61 bait ke 1, 3, 7, 11, 15,
19, 21 yang memiliki makna tidak sebenarnya. Bulan Purnama memiliki makna konotatif yaitu sesuatu yang memberikan petunjuk kepadanya, sedangkan makna sebenarnya berdasarkan KBBI adalah makna bulan langit yang melingkari bumi dan purnama saat bulan purnama berbentuk bulat. Selanjutnya pada halaman halaman 61 bait ke 1, 3, 7, 11, 15, 19, 21 memiliki makna konotatif yaitu sesuatu yang indah atau keindahan, sedangkan makna yang sebenarnya berdasarkan KBBI adalah bunga mawar yang sebenarnya atau berduli terletak di atas kami.

Pada judul "Miftaahul Jannah" terdapat makna konotatif pada kutipan Kunci Surga yang terdapat pada halaman 70 bait ke 1, 3, 7, 11, 13 yang memiliki makna tidak sebenarnya. Kunci Surga memiliki makna konotatif yaitu hal-hal yang sangat penting sebagai jalan menuju surga, sedangkan makna sebenarnya berdasarkan KBBI adalah kunci alat untuk mengancing atau menutup pintu dan surga adalah alam akhirat yang membahagiakan roh manusia yang hendak tinggal di dalamnya.

Pada kutipan di atas banyak terdapat makna-makna konotatif dalam naskah syair qasidah salawat nabi, yaitu dari 36 judul, terdapat 8 judul yang memiliki makna konotatif sebanyak 13 kutipan. Kutipan makna konotatif pada pembahasan di atas mengacu pada teori (Yayat Sudaryat, 2011:25).

\section{SIMPULAN}

Berdasarkan hasil penelitian dan pembahasan yang telah peneliti uraikan, makna konotatif cukup banyak digunakan dalam syair qasidah salawat nabi. Sebanyak 13 kalimat dari 36 judul memuat kata-kata bermakna konotatif. Dari 36 judul tersebut hanya terdapat 8 
judul yang ditemukan bermakna konotatif. Dalam satu judul terdapat lebih dari satu kata-kata konotatif.

\section{DAFTAR PUSTAKA}

Adrika Fitrhrotul Aini. (2014). Living Hadis Dalam Tradisi Malam Kamis Majelis Shalawat Addba'bil-Musafa. (Ar-Rainiry; Internaional Journal of Islamic Studies Vo. 2, No. 1. Juni 2014) hlm. 222. (diakses pada tanggal 10 Januari 2018).

Aji, Siswoko. (2015). “Analisis Makna pada Slogan Stasiun Televisi Nasional di Indonesia”. Skripsi.

Arikunto, Suharsimi. (2010). Prosedur Penelitian Suatu Pendekatan. Jakarta: Rineka Cipta.

Chaer, Abdul. (1990). Pengantar Semantik Bahasa Indonesia. Jakarta: Rineka Cipta.

Chaer, Abdul. (2009). Pengantar Semantik Bahasa. Jakarta: PT. Rineka Cipta.

Chaer, Abdul. (2011). Pengantar Semantik Bahasa Indonesia. Jakarta: Rineka Cipta.

Diyanti, Anita. (2000). “Kajian Semantik Wudud Onomatope dalam Komik Serial Donal Bebek”. Skripsi.

Hidayat, Asep Ahmad. (2006). Filsafat Bahasa: Mengungkapkan Hakikat Bahasa Makna dan Tanda. Bandung: PT. Remaja Rosdakarya.

Ibrahim. (2015). Metodologi Penelitian Kualitatif: Panduan Penelitian Beserta Contoh Proposal Kualitatif. Bandung: Alfabeta.

Keraf, Gorys. (2010). Diksi dan Gaya Bahasa. Jakarta: Penerbit Ikrar Mandiri.

Masduki, Aam dkk. (2005). Kesenian Tradisional Provinsi Banten Departemen Kebudayaan dan
Pariwisata Balai Kajian Sejarah dan Nilai Tradisional. Bandung.

Rahima, A. (2017). Interpretasi Makna Simbolik Ungkapan Tradisional Seloko Hukum Adat Melayu Jambi. Jurnal Ilmiah Universitas Batanghari Jambi,17(1), 250267.

Santosa, Puji dkk. (2008). Materi dan Pembelajaran Bahasa Indonesia. Jakarta: Universitas Terbuka.

Siswantoro, (2010). Metode Penelitian Sastra: Analisis Struktur Puisi.Yogyakarta: Pustaka Pelajar.

Sudaryat, Yayat. (2011). Makna dalam wacana: prinsip-psinsip semantik dan pragmatik. Bandung: Yrama Widya.

Sugiyono, (2015). Memahami Penelitian Kualitatif. Jakarta: PT. Gramedia Pustaka Utama.

Sujarno, Aris. (2010). “Analisis Semantik dalam Syair Kesenian Cowong di Desa Pekuncen Kecamatan Kroya Kabupaten Cilacap”. Skripsi: Mahasiswa Universitas Muhammadiyah Purwokerto.

Sunyiartiningsih. (2013). "Kajian Semantik pada Syair Lagu Kesenian Tradisional Kleningan Mekar Rahayu di Desa Sukarahayu, Kecamatan Langen Sari, Kota Banjar”. Skripsi: Universitas Muhammadiyah Purwokarto.

Yuniarti, Evi. (2014). “Kajian Semantik Nama Panggilan Unik Siswa di Sekolah Madrasah Aliyah Negeri Kraya Tahun Pelajaran 20132014". Skripsi.

Yusuf, Mohammad. (2009). Syair Cinta dalam Sastra Sufi. Jambi Timur: Sultan Thaha IAIN Sultan Thaha Saifuddin Jambi. 